Hodong Kim, Holy War in China: The Muslim Rebellion and State in Chinese Central Asia, 1864-1877

Stanford, California University Press, 2004, 295 p.

Alexandre Papas

URL : http://journals.openedition.org/chinaperspectives/1042

DOI : 10.4000/chinaperspectives.1042

ISSN : 1996-4617

Éditeur

Centre d'étude français sur la Chine contemporaine

Édition imprimée

Date de publication : 1 juillet 2006

ISSN : 2070-3449

Référence électronique

Alexandre Papas, « Hodong Kim, Holy War in China: The Muslim Rebellion and State in Chinese Central Asia, 1864-1877 », China Perspectives [En ligne], 66 | July- August 2006, mis en ligne le 01 juin 2007, consulté le 24 septembre 2020. URL : http://journals.openedition.org/chinaperspectives/1042 DOI : https://doi.org/10.4000/chinaperspectives.1042

Ce document a été généré automatiquement le 24 septembre 2020.

(c) All rights reserved 


\title{
Hodong Kim, Holy War in China: The Muslim Rebellion and State in Chinese Central Asia, 1864-1877
}

\author{
Stanford, California University Press, 2004, 295 p.
}

\section{Alexandre Papas}

\section{NOTE DE L'ÉDITEUR}

Translated from the French original by Jonathan Hall

1 Both in terms of its theme and its wealth of erudition, this book by the Korean historian, Hodong Kim, is an invaluable contribution to Central Asian studies, and a long-awaited worthy successor to the work of the late Joseph Fletcher. The Muslim rebellion in Eastern Turkestan and the Emirate established by Ya'qûb Beg from 1864 to 1877 represent a break in the history of modern China. This was a break in territorial, commercial and political terms. The author makes use of a wide and varied range of sources, from Chinese administrative archives to Russian military reports, and from Japanese studies to Turkestani lithography. The latter are central to Kim's documentary evidence because, coming from the very heart of the events, they provide us with a view of both the facts and their significance, which was very close to that of the historical protagonists themselves. Here is where this historian's main concern lies, to reconstruct the Turkestani point of view at a time when Eastern Turkestan achieved a unity and independence that was recognised by foreign states. Whether this was indeed historically unprecedented, as the writer states on page xiv, is a delicate matter to which I will be alluding throughout the present review. In so doing, I will highlight the politico-religious issues involved.

2 The book is organised into six chapters, and it starts with a description of the social and political situation in the early 1860 s (Chapter 1 ). Here he shows that, in addition to the series of rebellions shaking the whole of the north-western region, there were more 
structural reasons behind the weakening of the authority of the Qing empire, such as the lack of financial resources which increased abusive taxation and led to an extreme heightening of tensions. This explosive situation put the Chinese Muslims (Tungans) at the forefront of a violent insurrection, which then rapidly spread, reaching the towns of Kucha, Urumchi, Yarkand, Kashgar, Khotan, and Ili by the summer of 1864 (Chapter 2). In each case it would appear that the problem of leadership was posed. This is particularly interesting insofar as we seem to be dealing with conflicts over legitimacy and the exercise of power, not simply between Tungans and Turkic peoples, but more fundamentally between warlords, local nobility, and religious and/or Sufi authorities. Although the latter wielded scarcely any power, they nevertheless played an indispensable role as negotiators at the heart of the rebel factions or ethnic groups, and this points to a socio-political dimension to Islam in the region which is essential for understanding its modern history. It was precisely this dimension which led a Kirghiz rebel to call upon the Naqshbandî Sufi Sheikh, Buzurg Khwâja, and his general Ya'qûb Beg, to leave their neighbouring Ferghana to support the insurrection in Yarkand. These were the political and religious realities of the holy war in China (ghazât dar mulk$i$ chin). Ya'qûb Beg himself appears as a paradoxical figure in several respects (Chapter 3). Shrouded in historical uncertainties and retrospective legends, this future Emir of Eastern Turkestan rose through the military hierarchy of the Khanate of Khoqand, starting with his regency in Âq Masjid and later Khojand before being sent to Kashgar by the Khan 'Âlim Qulî. Although this successful career was due to his undeniable strategic skills, plus certain advantageous circumstances which gave him military superiority (analysed in detail by Hodong Kim), we should note Ya'qûb Beg's decisive move when he sidelined the two rivals Wâli Khân and Buzurg Khwâja, that is to say, the two holy Sufi authorities. Thanks to this, the general himself became the sole hero and unique standard bearer of the Islamic insurgency.

3 Chapter 4, devoted to the Muslim state founded by Ya'qûb Beg, is developed at greater length and is particularly enlightening. It shows that the Emirate was organised in a pyramidal structure with Ya'qûb Beg himself at the apex. But although he made himself the single judge and decision-maker in important matters, he was surrounded by court officials, including the mîrzâbashî (chancellors) who performed essential diplomatic and administrative functions (running taxation, the treasury, and the army). At a lower level, the territory was divided into several provinces (wilâyat). Each of these was under the control of a local governor (hâkim) appointed by Ya'qûb and placed in charge of administering the region's finances and police. Despite this, the legal system was in the hands of a traditional Muslim judiciary, the qâdi, mufti, and ra'îs. A second major feature concerns the establishment of a professional army along strictly hierarchical lines. Here too this work provides abundant details. Finally the point to be remembered is the general spirit of the Emirate. It proclaimed itself an Islamic regime, guaranteeing religious morality and breaking with the previous Qing order, which was considered to be infidel. So sharîa law was strictly applied; some Sufi orders seem to have suffered persecution while numerous religious sites (mainly mosques and holy mausoleums) were restored or newly built. Ya'qûb Beg's attitudes bear witness to the Islamic orthodoxy that his rule sought to impose on everyone.

This strong Islamic orientation is also to be found in the Emirate's foreign policy, as it is described in Chapter 5. Admittedly, the treaties made with Britain and Russia, i. e., with two out of the three major powers in the region, represent unprecedented diplomatic openings for Eastern Turkestan. But the latter's perspectives were clearly more 
focussed on the Muslim world when in 1865 Sayyid Ya'qûb Khân, its emissary to Istanbul, capital of the Caliphate, requested political and military support from the Ottoman Empire for the Emirate of Kashgar, all in the name of Islam. He was to return again in 1873 to repeat this request to the Sultan 'Abdülazîz, receiving satisfaction on that occasion. In addition to Ya'qûb Beg's political ability, this also shows to what extent Islam in the frontier regions of China and Turkestan was an indispensable source of legitimacy, recognition, and in the end, material aid. An appeal was made to the idea of the unity of the Muslim world, representing a break in which China stood for the infidel in opposition to the lands of Islam. Although this ideal did not prevent the fall of the Kashgar Emirate and its reincorporation into the Qing empire after 1877 (Chapter 6), it is still important to grasp the historical significance of this moment of Eastern Turkestan's unity and independence.

From a politico-religious point of view, these thirteen years are neither a unique moment nor a first occurrence. In fact there is a historical continuity. In a similar series of events between 1680 and 1694 the Sufi holy man Khwâja Âfâq, with the support of the Junggar Mongols, had overthrown Shaghatayid domination and set up a Sultanate in Kashgar (dâr al-sultanat-i kâshgar) based on the principles of Islam and Sufism. The fact that historians have become accustomed to seeing this as just an episode in the final period of Junggar suzerainty does not alter the point that this was a period of independence and unity fully recognised by the neighbouring states (the Khanate of Bukhara, the Lamaist theocracy of Tibet, and the Qing Empire) as well as their Turkestani rivals. It was not by chance-indeed it was a highly meaningful move on his part-that Ya'qûb Beg, on the day after receiving Ottoman recognition, organised an investiture ceremony in the mausoleum of Khwâja Âfâq, a site of religious and political commemoration. Nor is it surprising to encounter the continuing religious tradition that led to Ya'qûb Beg being buried in the cemetery adjoining the mausoleum. 